\title{
Obituary
}

\section{Baron de Gerlache}

$\mathrm{A}^{\mathrm{D}}$ DRIEN DE GERLACHE DE GOMERY died in his sixty-ninth year on December 4 . When a young lieutenant in the Belgian navy, he conceived the idea of organising an expedition of his own to explore the antarctic regions and had his plans complete in 1894 for a voyage of adventurous discovery. Before he succeeded in raising the very modest sum needed to purchase and equip the Belgica, he was induced to make scientific research the main object of the expedition, and with this in view he secured the voluntary help of a group of enthusiastic young specialists including Prof. $\mathrm{H}$. Arctowski as geologist and Dr. F. A. Cook, the only member with polar experience, as surgeon. Roald Amundsen was first officer and the crew was half Belgian and half Norwegian. The Belgica sailed in August 1897 and spent some time amongst the islands of Tierra del Fuego, not reaching Hughes Gulf on the coast of Palmer Land until January 23, 1898. Here Gerlache discovered the strait which now bears his name cutting off three large islands from the northern extension of Graham Land. He explored and charted the coasts of this strait and large geological and natural history collections were made. The commander and his scientific staff were now at crosspurposes. He aspired to push on, perhaps to the Pole; they were anxious to remain investigating the rocks and glaciers, birds and marine organisms of a region never before touched by science. The ship went on.

Fast ice prevented any approach to the southern part of Graham Land, and the Belgica was headed south-west in an endeavour to reach a high latitude. Gerlache entered the pack early in March, too late in the season, and was unable to extricate the ship, which was frozen in. Thus, contrary to his plan, Gerlache was committed to the first wintering in the antarctic regions, for which the ship was ill-prepared and the provisions unsuited. During the year that followed, the Belgica drifted in all directions with the pack, sighting no land but making valuable soundings. The health of all on board suffered greatly, and Danco, one of the scientific staff, died of exhaustion. Before this drift, nothing whatever was known of winter conditions in the Antarctic, and the meteorological observations were thus very important. It was largely due to the courage and tenacity of Gerlache that the party emerged with all its collections in good condition. The large number of antarctic expeditions in the early years of the twentieth century eclipsed to some extent the pioneer work of the Belgica; but the imposing array of scientific results produced at the cost of the Belgian Government is an abiding monument.

Gerlache continued to interest himself in polar matters. He commanded the Belgica in the Duke of Orlean's scientific expedition to the East Greenland Sea in 1905 and he promoted the building of a fine ice-protected ship designed for sporting cruises about Spitsbergen. The ship was built, and though the project failed, Gerlache had the satisfaction of transferring her to Sir Ernest Shackleton in 1914 and superintended her adaptation as the Endurance for the ill-fated expedition to the Weddell Sea.

The slow publication of the Belgica results, long suspended by the War, left Gerlache with the last volume of the official narrative practically finished but still unpublished at his death. King Albert created him a Baron in recognition of his great achievements, but Gerlache remained one of the most modest of men and generously allowed his scientific staff all the credit for the work of his expedition.

H. R. M.

\section{Dr. N. E. Brown}

Nicholas Edward Brown, or "N. E. Br", as he was known to botanists all over the world, died on November 25 at his residence in The Avenue, Kew Gardens, after a few months' illness. This indefatigable taxonomic botanist seemed as keenly interested as ever in his subject at eighty-five years of age, and he was still busy with a monograph of Conophytum (a segregate from Mesembryanthemum), for which he had prepared a number of beautifully drawn and coloured plates with minute dissections. He was a very good botanical artist, and a skilful microscopist, being a member of the Quekett Club.

Brown was a native of Redhill, and was educated at the Reigate Grammar School. On leaving school he was employed for a few years in the latter town as curator of Mr. Wilson Saunders' Museum of Natural History, whence he migrated to the Kew Herbarium in 1873. There he remained until his retirement in 1914. His work at Kew was mainly concerned with the botany of tropical and South Africa, and he was the acknowledged authority on the flora of the latter country. It was largely through his efforts that the "Flora Capensis" was completed. $\mathrm{He}$ was an expert on succulent plants and such difficult families as Asclepiadaceae, Ericaceae, Euphorbiaceae, Iridaceae, etc. For many years after his retirement, Brown studied the large genus Mesembryanthemum, finding in that assemblage a great number of smaller genera.

Brown had been an associate of the Linnean Society since 1879, and in 1921 was awarded the Captain Scott Memorial Medal by the South African Biological Society in recognition of his work on the South African flora. In 1932, the University of the Witwatersrand, Johannesburg, conferred on him the honorary degree of doctor of science. He was a lifelong philatelist.

J. H.

Prof. Mikhailo Hrushevsky, a prominent Ukrainian historian, died in Moscow on November 26, aged sixty-eight years. He was for many years president of the Ukrainian Scientific Shevehenko Society and editor of many scientifie journals in Lwow and Kiev. 